\title{
Phylogenetic diversity of 'Endomicrobia' and their specific affiliation with termite gut flagellates
}

\author{
Correspondence \\ Andreas Brune \\ brune@mpi-marburg.mpg.de
}

Received 19 April 2007

Revised 22 June 2007

Accepted 27 June 2007
Wakako Ikeda-Ohtsubo, Mahesh Desai, Ulrich Stinglt and Andreas Brune

\author{
Max-Planck-Institut für terrestrische Mikrobiologie, Karl-von-Frisch-Strasse, 35043 Marburg, \\ Germany
}

\begin{abstract}
'Endomicrobia', a distinct and diverse group of uncultivated bacteria in the candidate phylum Termite Group I (TG-1), have been found exclusively in the gut of lower termites and woodfeeding cockroaches. In a previous study, we had demonstrated that the 'Endomicrobia' clones retrieved from Reticulitermes santonensis represent intracellular symbionts of the two major gut flagellates of this termite. Here, we document that 'Endomicrobia' are present also in many other gut flagellates of lower termites. Phylogeny and host specificity of 'Endomicrobia' were investigated by cloning and sequencing of the small subunit rRNA genes of the flagellate and the symbionts, which originated from suspensions of individual flagellates isolated by micropipette. Each flagellate harboured a distinct phylogenetic lineage of 'Endomicrobia'. The results of fluorescent in situ hybridization with 'Endomicrobia'-specific oligonucleotide probes corroborated that 'Endomicrobia' are intracellular symbionts specifically affiliated with their flagellate hosts. Interestingly, the 'Endomicrobia' sequences obtained from flagellates belonging to the genus Trichonympha formed a monophyletic group, suggesting co-speciation between symbiont and host.
\end{abstract}

\section{INTRODUCTION}

'Endomicrobia' are a distinct and diverse group of uncultivated bacteria in the candidate phylum Termite Group I (TG-1) (Hugenholtz et al., 1998; Stingl et al., 2005). Originally discovered as members of the hindgut community of Reticulitermes speratus (Ohkuma \& Kudo, 1996; Hongoh et al., 2003), their occurrence seems to be restricted to the guts of phylogenetically lower termites and wood-feeding cockroaches (Cryptocercus punctulatus) (Hongoh et al., 2005; Stingl et al., 2005; Yang et al., 2005). We have demonstrated previously that the 'Endomicrobia' clones retrieved from Reticulitermes santonensis represent intracellular symbionts of flagellate protists (as previously proposed by Ohkuma et al., 2001), and documented that the two major gut flagellates of this termite, Trichonympha agilis and Pyrsonympha vertens, each harbour a phylogenetically distinct lineage of 'Endomicrobia' (Stingl et al., 2005).

Termite gut flagellates are a unique group of protists consisting of more than 430 species, which have been

tPresent address: Oregon State University, Department of Microbiology, Nash Hall 220, Corvallis, OR 97331, USA.

Abbreviations: FISH, fluorescence in situ hybridization; SSU, small subunit.

The GenBank/EMBL/DDBJ accession numbers for the nucleotide sequence data reported in this paper are AB297984-AB298082, AB326107, AB326370-AB326383, AM747388 and AM747389. described mostly on a morphological basis (Brugerolle \& Lee, 2000; Yamin, 1979). Phylogenetic studies using smallsubunit (SSU) rRNA and other molecular markers have confirmed the presence of two distinct phylogenetic lineages, i.e. Oxymonadida and Parabasalidea (Dacks et al., 2001; Gerbod et al., 2002; Stingl \& Brune, 2003; Ohkuma et al., 2005). Although little is known about the metabolic functions of termite gut flagellates (Brune \& Stingl, 2005) - the majority of which are uncultivated they are generally considered to play a major role in the cellulose metabolism of the hindgut (Yamin, 1980; Odelson \& Breznak, 1985).

Most termite gut flagellates are associated with prokaryotic symbionts, which colonize the cell surface, the cytoplasm or sometimes the nucleus of their hosts (Kirby, 1941; Berchtold et al., 1999; Brune \& Stingl, 2005; Brune, 2006). The high frequency of such associations and an apparent specificity of the symbionts for their host flagellate (Noda et al., 2005, 2006; Stingl et al., 2004) are indicative of a functional significance of such symbioses for the termite gut ecosystem.

The symbiosis between 'Endomicrobia' and termite gut flagellates might also represent such an intimate relationship, which has been supported by evidence that some 'Endomicrobia' form host-specific associations with their host flagellate (Stingl et al., 2005). Furthermore, the wide distribution and phylogenetic heterogeneity of 'Endomicrobia' among lower termites harbouring various gut 
flagellates (Stingl et al., 2005) collectively suggest a strong connection between the phylogenetic diversity of the symbionts and their flagellate hosts. We hypothesize here that the phylogenetic diversity of 'Endomicrobia' in the gut of lower termites reflects the diversity of their flagellate hosts. To test this hypothesis, we phylogenetically analysed SSU rRNA genes of the major flagellates and their symbionts in the termite Hodotermopsis sjoestedti and in selected flagellates of five other termite species.

\section{METHODS}

Termites. Hodotermopsis sjoestedti was collected on Yakushima Island, Japan. Zootermopsis nevadensis was collected on Mt Pinos, Los Padres National Forest, California, USA. Cryptotermes secundus came from a mangrove forest near Darwin, Australia. Mastotermes darwiniensis, Kalotermes flavicollis and Neotermes castaneus were from cultures maintained at the Bundesanstalt für Materialforschung und -prüfung (BAM), Germany. In the laboratory, colonies were maintained in polyethylene containers at $25^{\circ} \mathrm{C}$ on a diet of pinewood. Only termite workers/pseudergates were used in the experiments.

DNA extraction from whole hindguts. Ten hindguts were dissected using sterile forceps and pooled in $750 \mu$ l filter-sterilized sodium phosphate buffer ( $\mathrm{pH}$ 8.0) in a polyethylene tube. The entire content of the tube was transferred into a polyethylene screw-cap tube containing $250 \mu \mathrm{l}$ TNS solution $(500 \mathrm{mM}$ Tris/ $\mathrm{HCl}, 100 \mathrm{mM} \mathrm{NaCl}, 10 \%$ SDS, $\mathrm{pH} 8.0)$ and $0.7 \mathrm{~g}$ zirconium beads, and then homogenized in a FastPrep FP120 (Bio 101, Savant Instruments) for $45 \mathrm{~s}$ at $6.5 \mathrm{~m} \mathrm{~s}^{-1}$. The homogenates were centrifuged, and DNA in the supernatant was purified by phenol/chloroform extraction and ethanol precipitation.

DNA extraction from flagellates. The contents of three to seven hindguts were suspended in Solution U (Trager, 1934) and diluted to a density of approximately 10 flagellate cells $\mu \mathrm{l}^{-1}$. Aliquots $(20 \mu \mathrm{l})$ of the diluted suspension were placed in the wells of a 10-well Tefloncoated glass slide (Erie Scientific Company). Flagellate cells were sorted by morphology (Radek et al., 1992; Tamm, 1999; Brugerolle \& Bordereau, 2004), and 150-200 flagellate cells of each morphotype were collected by micropipette using an inverted microscope. The cells were collected into a well containing $15 \mu \mathrm{l}$ sterile PBS and washed by at least three transfers into fresh PBS-containing wells. Approximately 100 cells were finally resuspended in $200 \mu \mathrm{l}$ sterile PBS. Cells were disrupted by three cycles of freeze-thawing, and DNA was extracted from each sample using the NucleoSpin kit (MachereyNagel), following the manufacturer's instructions. The extracted DNA was finally eluted with $30 \mu \mathrm{l}$ distilled water and used as a template for PCR reactions.

PCR amplification. Flagellate SSU rRNA genes were amplified using universal eukaryotic primers as described by Keeling et al. (1998). Bacterial SSU rRNA genes were amplified using 27F (Edwards et al., 1989) and 1492R (Weisburg et al., 1991) as described by Henckel et al. (1999). 'Endomicrobia' SSU rRNA genes were amplified as previously described, using the forward primer TG1-209F (Stingl et al., 2005) and a slightly modified reverse primer TG1-1325R' (5'GATTCCTACTTCATGTG-3').

Cloning and sequencing. PCR products were ligated into plasmid pCR2.1-TOPO and introduced into E. coli TOP10F' by transformation using the TOPO TA cloning kit (Invitrogen), following the manufacturer's instructions. Clones with a flagellate SSU rRNA gene insert and clones with an 'Endomicrobia' SSU rRNA gene insert
( 1070 bp) were screened by direct PCR using M13 primers. To obtain the almost-full-length 'Endomicrobia' SSU rRNA genes, bacterial SSU rRNA gene libraries ( 1500 bp) were screened with 'Endomicrobia'-specific primers (see above). PCR products of the expected size were digested separately with the restriction enzymes MspI and $A l u \mathrm{I}$, and subjected to electrophoresis on a 3\% agarose gel. The clones were sorted according to their restriction patterns, and two to ten representatives of each ribotype were sequenced using M13 primer sets. For each phylotype (sequence clusters with more than $1 \%$ sequence divergence) obtained in this study, several representative SSU rRNA gene sequences have been submitted to GenBank under accession numbers AB297984-AB298082, AB326107, AB326370-AB326383 and AM747388-AM747389.

Phylogenetic analysis. The SSU rRNA gene sequences were imported into the database implemented in the ARB software package (Ludwig et al., 2004). The sequences were automatically aligned with the other closely related SSU rRNA sequences using the ARB Fast_Aligner, followed by manual refinement. Phylogenetic trees were constructed using almost-full-length SSU rRNA sequences ( $>1300$ bases) by maximum-likelihood methods (AxML and fastDNAml), and the stability of the tree topology was tested by the neighbour-joining and maximum-parsimony methods implemented in ARB. Shorter sequences were added using the ARB parsimony tool. Chimaeric sequences were identified using the Bellerophon server (Huber et al., 2004; http://foo.maths.uq.edu.au/ huber/bellerophon. $\mathrm{pl}$ ) and by carefully checking for signature sequences in the alignment, and were subsequently removed from the dataset.

Whole-cell in situ hybridization. Fixed gut contents were prepared and in situ hybridization was performed as described previously (Stingl \& Brune, 2003). Probe EUB338 (Amann et al., 1990) and the nonsense probe NON338 (Wallner et al., 1993) were used to identify bacterial cells and to distinguish non-specific probe binding in the same suspension. For each probe, hybridization stringency was optimized by testing formamide concentrations over a range of $0-50 \%$.

\section{RESULTS}

\section{Host affiliation of 'Endomicrobia' in $\boldsymbol{H}$. sjoestedti}

Clone libraries of SSU rRNA genes amplified from $H$. sjoestedti whole-gut DNA extract with 'Endomicrobia'specific primers contained more than 10 distinct monophyletic lineages of 'Endomicrobia'. To test whether individual phylotypes can be assigned to their host flagellates, suspensions were prepared by carefully picking individual flagellate cells according to their characteristic morphotypes. The major populations among the flagellate community were formed by species of the genus Dinenympha (Oxymonadida; Fig. 1a), Trichonympha and Eucomonympha (both Parabasalidea; Fig. 1b, c). DNA extracted from the respective suspensions yielded PCR products of the expected length with eukaryotic (1500$1800 \mathrm{bp})$, bacterial ( 1500 bp) and 'Endomicrobia'-specific ( 1100 bp) SSU rRNA primers.

The eukaryotic SSU rRNA gene libraries prepared from the Eucomonympha and Dinenympha suspensions each contained a single phylotype (Table 1). In the library from the Eucomonympha suspension, the obtained sequence was virtually identical to that of clone HsL3 recovered in a clone library of a mixed flagellate population of $H$. 

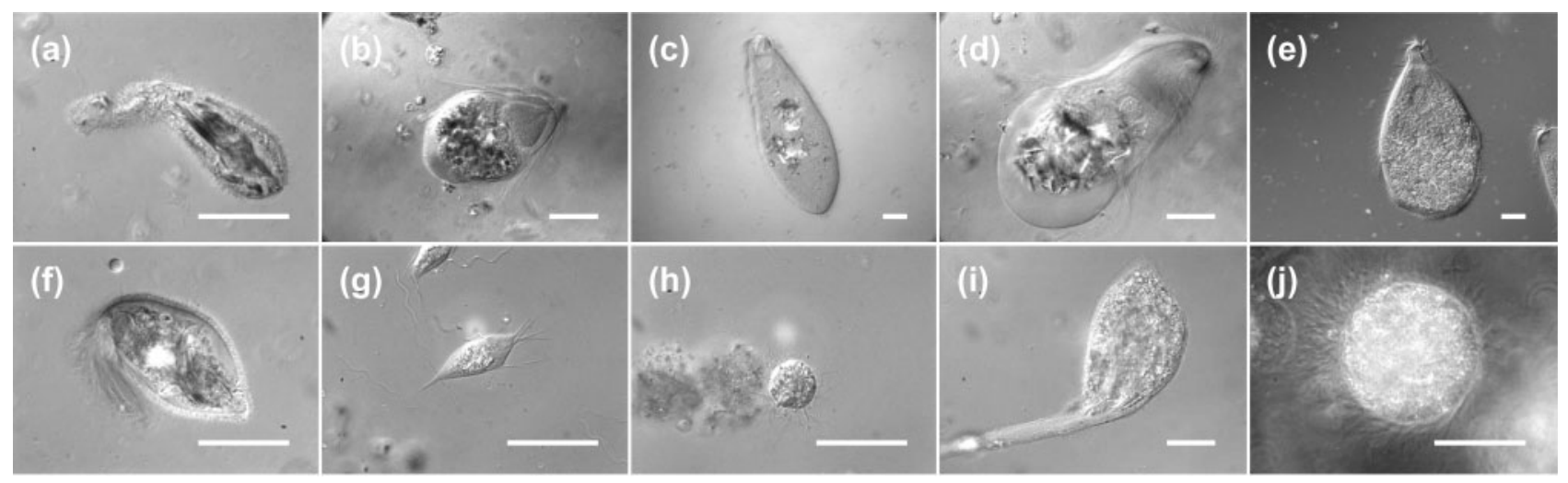

Fig. 1. Light micrographs of ten flagellate species used in this study: Dinenympha sp. (a), Trichonympha sp. (b) and Eucomonympha sp. (c) from H. sjoestedti; Trichonympha sp. (d) from Z. nevadensis; Deltotrichonympha sp. (e) from M. darwiniensis; Joenia sp. (f) from K. flavicollis; Devescovina sp. (g), Calonympha sp. (h) and Oxymonas sp. (i) from N. castaneus; and an unclassified parabasalid (j) from C. secundus. Bars, $50 \mu \mathrm{m}$.

sjoestedti (Ohkuma et al., 2000), corroborating the tentative assignment of this clone to the genus Eucomonympha. In the case of the Dinenympha suspension, the sequence showed $94 \%$ identity to that of a Dinenympha species from Reticulitermes hesperus (Moriya et al., 2003) and probably represents a new, hitherto unrecognized species of

Table 1. Phylotypes of flagellates recovered in the flagellate suspensions prepared from hindgut contents of different termite species and their closest relatives in public databases

\begin{tabular}{|c|c|c|c|c|}
\hline Termite species (family) & Flagellate suspension $\left(\right.$ Order $\left.^{\star}\right)$ & $\begin{array}{c}\text { Flagellate } \\
\text { phylotype } \\
\text { (accession no.) }\end{array}$ & Closest relatives (accession no.) & $\begin{array}{c}\text { Sequence } \\
\text { similarity } \\
(\%) \dagger\end{array}$ \\
\hline \multirow[t]{5}{*}{$\begin{array}{l}\text { Hodotermopsis sjoestedti } \\
\text { (Termopsidae) }\end{array}$} & \multirow[t]{3}{*}{$\begin{array}{l}\text { Trichonympha } \\
\text { (Trichonymphida) }\end{array}$} & $\begin{array}{c}\text { HsTcA } \\
(\mathrm{AB} 326107)\end{array}$ & $\begin{array}{l}\text { Trichonympha sp. HsL5 from H. sjoestedti } \\
\text { (AB032233) }\end{array}$ & 99.9 \\
\hline & & $\begin{array}{l}\mathrm{HsTcB} \\
(\mathrm{AB} 326371)\end{array}$ & $\begin{array}{l}\text { Trichonympha sp. Hs8 from H. sjoestedti } \\
\text { (AB032229) }\end{array}$ & 99.5 \\
\hline & & $\begin{array}{l}\text { HsTcC } \\
(\mathrm{AB} 326373)\end{array}$ & $\begin{array}{l}\text { Trichonympha sp. HsS9 from H. sjoestedti } \\
\text { (AB032239) }\end{array}$ & 99.6 \\
\hline & $\begin{array}{l}\text { Eucomonympha } \\
\text { (Trichonymphida) }\end{array}$ & $\begin{array}{c}\text { HsEcA } \\
(\mathrm{AB} 326375)\end{array}$ & $\begin{array}{l}\text { Eucomonympha sp. HsL3 from H. sjoestedti } \\
\text { (AB032231) }\end{array}$ & 99.0 \\
\hline & Dinenympha (Oxymonadida) & $\begin{array}{l}\text { HsDnA } \\
(\mathrm{AB} 326376)\end{array}$ & $\begin{array}{l}\text { Dinenympha sp. OS1 from } R \text {. hesperus } \\
\text { (AB092933) }\end{array}$ & 94.0 \\
\hline $\begin{array}{l}\text { Zootermopsis nevadensis } \\
\text { (Termopsidae) }\end{array}$ & $\begin{array}{l}\text { Trichonympha } \\
\text { (Trichonymphida) }\end{array}$ & $\begin{array}{c}\mathrm{ZnTcA} \\
(\mathrm{AB} 326378)\end{array}$ & $\begin{array}{l}\text { Trichonympha cf. collaris from Z. angusticollis } \\
\text { (AF023622) }\end{array}$ & 95.2 \\
\hline $\begin{array}{l}\text { Mastotermes darwiniensis } \\
\text { (Mastotermitidae) }\end{array}$ & $\begin{array}{l}\text { Deltotrichonympha } \\
\text { (Christamonadida) }\end{array}$ & $\begin{array}{l}\text { MdDtA } \\
(\mathrm{AB} 326380)\end{array}$ & $\begin{array}{l}\text { Deltotrichonympha operculata from } \\
\text { M. darwiniensis (AJ583379) }\end{array}$ & 99.5 \\
\hline $\begin{array}{l}\text { Kalotermes flavicollis } \\
\text { (Kalotermitidae) }\end{array}$ & Joenia (Cristamonadida) & $\begin{array}{c}\text { KfJeA } \\
(\mathrm{AB} 326381)\end{array}$ & Gut symbiont Kf5 from K. flavicollis (AF215857) & 98.7 \\
\hline \multirow[t]{3}{*}{$\begin{array}{l}\text { Neotermes castaneus } \\
\text { (Kalotermitidae) }\end{array}$} & Devescovina (Cristamonadida) & $\begin{array}{c}\text { NcDvA } \\
(\mathrm{AM} 747389)\end{array}$ & Devescovina sp. D16 from N. jouteli (X97974) & 98.9 \\
\hline & Calonympha (Cristamonadida) & $\begin{array}{c}\mathrm{NcClA} \\
(\mathrm{AM} 747388)\end{array}$ & Calonympha sp. B14 from N. jouteli (X97976) & 98.5 \\
\hline & Oxymonas (Oxymonadida) & $\begin{array}{c}\mathrm{NcOxA} \\
(\mathrm{AB} 326383)\end{array}$ & $\begin{array}{l}\text { Oxymonas sp. Nk_U08 from N. koshunensis } \\
\text { (AB092931) }\end{array}$ & 94.5 \\
\hline $\begin{array}{l}\text { Cryptotermes secundus } \\
\text { (Kalotermitidae) }\end{array}$ & $\begin{array}{l}\text { Unclassified parabasalid } \\
\text { (Cristamonadida) }\end{array}$ & CsSnA & $\begin{array}{l}\text { Unclassified parabasalid from C. brevis } \\
\text { (AF052699) }\end{array}$ & 96.1 \\
\hline
\end{tabular}

${ }^{\star}$ Affiliation is based on Ohkuma et al. (2005).

$\dagger$ Calculated based on the aligned dataset using ARB. 
Dinenympha. The Trichonympha suspension yielded three different phylotypes of eukaryotic SSU rRNA genes, whose sequences were virtually identical to those of the three Trichonympha phylotypes previously obtained from this termite by Ohkuma et al. (2000).

SSU rRNA gene libraries were constructed from the same flagellate suspensions using Bacteria-specific or 'Endomicrobia'-specific primers. With either primer set, only a single phylotype of 'Endomicrobia' was recovered from the Dinenympha ('Endomicrobia' phylotype $\mathrm{HsDn}-1$ ) and Eucomonympha (HsEc-1) suspensions, whereas two distinct phylotypes (HsTc-1 and HsTc-2) were identified in the Trichonympha suspension. Each of the phylotypes formed a distinct, host-specific cluster (Fig. 2). Additional clusters consisting only of clones from whole-gut preparations were present (WG1-WG9, Fig. 2), suggesting that 'Endomicrobia' might be present also in other flagellate species in $H$. sjoestedti other than those investigated. However, we do not completely preclude the possibility that these unidentified clones are derived from free-living 'Endomicrobia' species.

\section{'Endomicrobia' in representative flagellates from other termites}

Using the same strategy, we phylogenetically analysed the host flagellates and 'Endomicrobia' in the flagellate suspensions prepared from five other termites, which represent seven additional flagellate genera of parabasalids and oxymonadids (Table 1). Again, we were able to assign the eukaryotic SSU rRNA gene sequences obtained from each flagellate suspension to the identical or similar respective genera, whose SSU rRNA gene sequences have been published. A notable exception was the SSU rRNA gene recovered from the suspension of Joenia sp. of $K$. flavicollis, which showed the highest identity (98\%) to clone Kf5 (AF215857) obtained from a clone library of the same termite and assigned to the flagellate genus Foaina by other authors (Gerbod et al., 2000).

Each of the flagellate suspensions yielded a single and unique host-specific phylotype of 'Endomicrobia' in the corresponding SSU rRNA libraries. The phylogenetic tree of all almost-full-length (>1400 bp) SSU rRNA gene sequences obtained in this and previous studies clearly

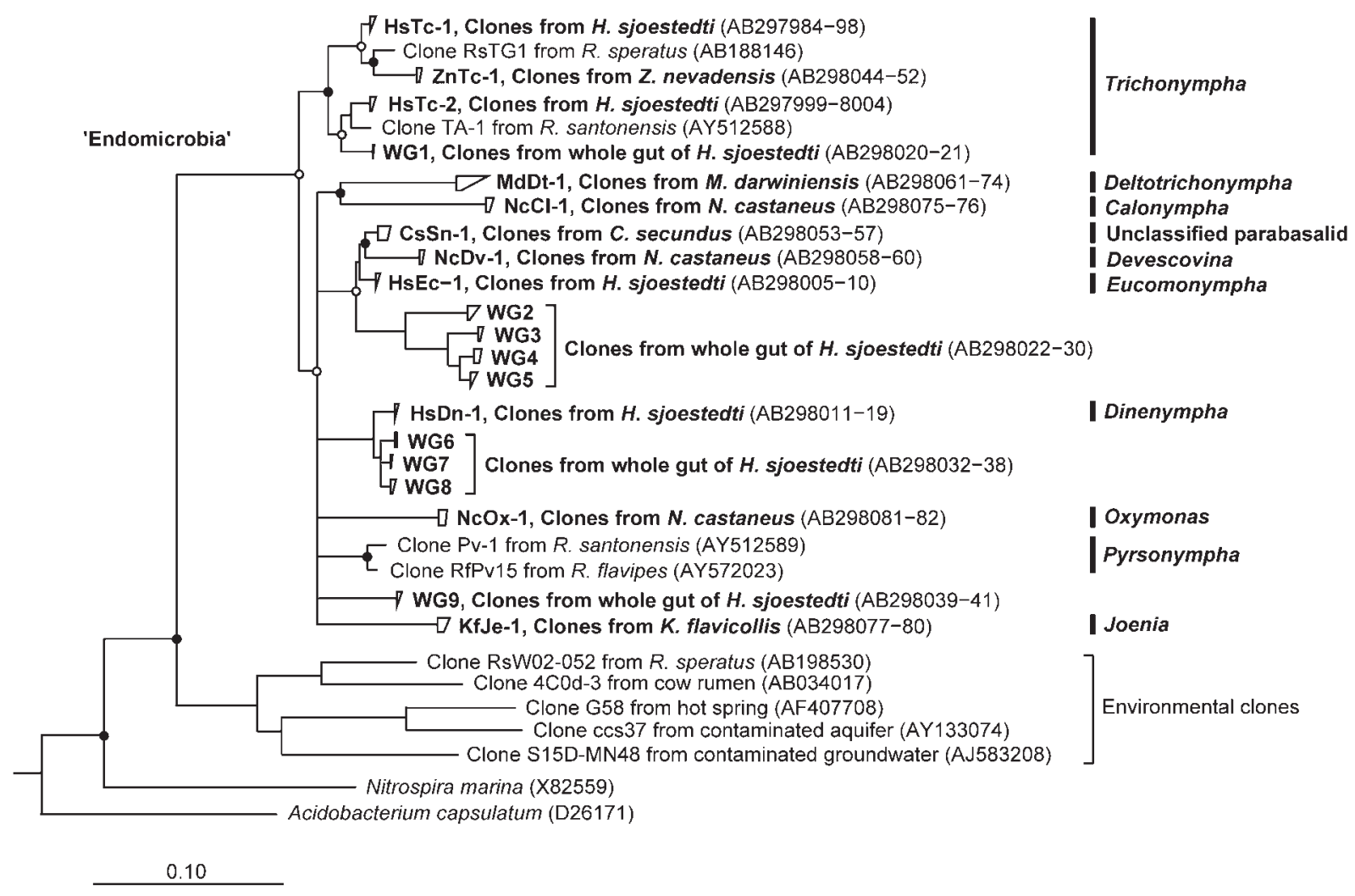

Fig. 2. Phylogenetic tree of 'Endomicrobia' and selected environmental clones in the TG-1 phylum, based on SSU rRNA gene sequences. The core tree (maximum-likelihood) was constructed from almost-full-length sequences ( $>1300$ bp). Tree topology was tested by neighbour-joining and parsimony analysis with bootstrapping (DNAPARS, 1000 replicates). Marked nodes have bootstrap values of $>95 \%(\bullet)$ and $>50 \%(\bigcirc)$, nodes not supported by all analyses are shown as multifurcations. WG1WG9: clusters formed by shorter ( 1070 bp) 'Endomicrobia' sequences originating from whole-gut contents added using the ARB parsimony tool. Sequences obtained in this study are marked in bold. 
showed that the 'Endomicrobia' sequences from each flagellate host always represent distinct phylotypes (Fig. 2). The 'Endomicrobia' of flagellates originating from the same termite did not cluster with each other. Instead, the 'Endomicrobia' from the Trichonympha species of $H$. sjoestedti and $Z$. nevadensis clustered together with those previously obtained from the Trichonympha species of $R$. santonensis and $R$. speratus, and collectively constitute a monophyletic cluster that forms a sister group of the 'Endomicrobia' clones recovered from all other flagellates.

\section{Localization of 'Endomicrobia' by fluorescence in situ hybridization (FISH)}

For selected termites, we conducted FISH to confirm the intracellular location of the 'Endomicrobia' phylotypes obtained from the respective flagellate suspensions by the specific PCR amplification. It was not possible to design a specific probe for all 'Endomicrobia'. Moreover, the limited number of variable regions among different 'Endomicrobia' did not allow the design of specific probes covering each phylotype. Therefore, we designed a set of oligonucleotide probes that covered the phylotypes in question (Table 2).

Simultaneous FISH was conducted with a fluoresceinlabelled bacterial probe and a Cy3-labelled 'Endomicrobia' probe. Fig. 3 shows representative examples in which the 'Endomicrobia'-specific signal is exclusively localized within the corresponding host cells, whereas the Bacteriaspecific probe also stained bacteria associated with the surface or content of these and other flagellate species (Fig. 3). In no case did we see evidence for the location of 'Endomicrobia' on the cell surface or within the nucleus of the host.

Since the morphotypes of certain flagellates (Dinenympha spp. in $H$. sjoestedti and Joenia sp. in K. flavicollis) were difficult to distinguish in the fixed samples, the presence of 'Endomicrobia' in the host cells was also confirmed by double hybridization with the respective combination of host and symbiont probes (Table 2; details not shown). In the case of Eucomonympha cells, it was not possible to visualize single cells of 'Endomicrobia' because of a high affinity of both the Bacteria-specific and nonsense probe to the dense cell content of the host flagellate. Fluorescence signals outside of the flagellate cells observed in dry-wood termites (see Fig. 3f) were present also in non-stained preparations and were caused by autofluorescence of wood particles in the gut content.

\section{DISCUSSION}

The results of this study corroborate that 'Endomicrobia' are host-specific intracellular symbionts of termite gut flagellates. Each of the flagellates investigated harboured a unique phylotype of 'Endomicrobia', which supports our hypothesis that the diversity of 'Endomicrobia' in each termite gut reflects the diversity of their flagellate hosts. Potential co-speciation between endosymbiont and host is suggested by the 'Endomicrobia' phylotypes associated with flagellates of the genus Trichonympha constituting a monophyletic group.

Each of the termite gut flagellates analysed in this study invariably harboured 'Endomicrobia'. Together with the phylotypes that remain to be assigned to a particular host, 'Endomicrobia' represent the symbionts of up to 24 parabasalid and oxymonadid species, and probably more in view of the presence of 'Endomicrobia' phylotypes retrieved from whole-gut homogenates of $H$. sjoestedti in addition to those retrieved from the flagellate suspensions. The wide host range and their consistent occurrence within the host indicate a broad host spectrum of 'Endomicrobia' as symbionts of termite gut flagellates.

The 'Endomicrobia' of each flagellate species form a unique phylogenetic lineage. The case of $H$. sjoestedti, in which the Trichonympha suspension contained three phylotypes of

Table 2. Oligonucleotide probes newly designed for whole-cell hybridization of 'Endomicrobia' and their host flagellates

\begin{tabular}{|c|c|c|c|}
\hline Probe name & Target $^{*}$ & Sequence $\left(5^{\prime}-3^{\prime}\right) \dagger$ & Formamide concn $(\%)$ \\
\hline TG1End1023T1 & 'Endomicrobia' phylotypes ZnTc-1, HsTc-1, RsTG1 & GCTGACTCCCTTGCGGGTCA & $20-50$ \\
\hline TG1End1027 & Most 'Endomicrobia' lineages (including HsDn-1) & CTCTGCTAACTCCCTTGCGG & 40 \\
\hline TG1End1023 & Some 'Endomicrobia' lineages (including HsEc-1) & ACTAACTCCCTTGCGGGTCA & $20 \ddagger$ \\
\hline TG1-TriG1-Hsj & Symbiont HsTc-1 of Trichonympha sp. HsTcA & TTGGTCCAGAAGACTGCTT & 20 \\
\hline TG1-Joe-Kf & Symbiont KfJe-1 of Joenia sp. KfJeA & GCTAACTCTCTTGCGAGTCA & 20 \\
\hline TG1-Dev-Nca & Symbiont NcDv-1 of Devescovina sp. NcDvA & GCATAGGACCACAGTTTGGC & 20 \\
\hline Flg-Dine-Hsj & Dinenympha sp. HsDnA of $H$. sjoestedti & GCTTTTTGAGGCGGCTAT & 35 \\
\hline Flg-Trichol-Hsj & Trichonympha sp. HsTcA of H. sjoestedti & GCTAGATTTCAAGATAGTCT & 10 \\
\hline Flg-Euc-Hsj & Eucomonympha sp. HsEcA of H. sjoestedti & AAACCTCCAGACCACGCT & $10 \ddagger$ \\
\hline Flg-Joe-Kfl & Joenia sp. KfJeA of $K$. flavicollis & GCTAGGTTGCACACTAGTGG & 35 \\
\hline
\end{tabular}

*All 'Endomicrobia' probes had at least two mismatches against any other bacterial phylotype in public databases previously detected in termite guts. $\dagger$ The oligonucleotide probe sequences have been submitted to probeBase (Loy et al., 2003; www.microbial-ecology.net/probebase/).

$\$$ Not optimized. 

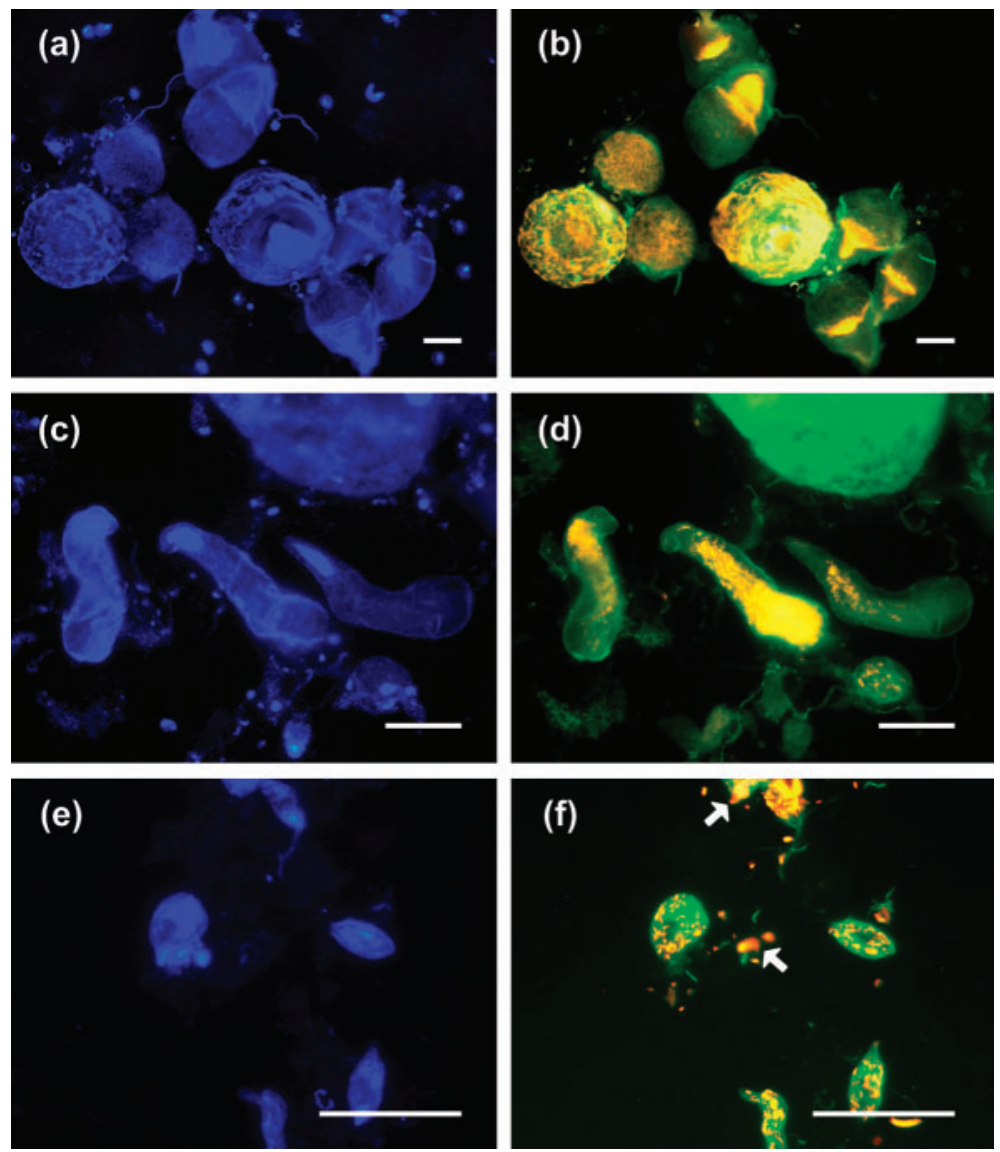

Fig. 3. Epifluorescence micrographs of hindgut preparations of $Z$. nevadensis $(a, b), H$. sjoestedti (c, d) and Devescovina from $N$. castaneus $(e, f)$. The preparations were stained with DAPI (a, c, e) and simultaneously hybridized with the fluorescein-labelled (green) probe EUB338 and the Cy3-labelled (orange) probes TG1End1023T1 (b), TG1End1027 (d), or TG1-Dev-Nca (f). Bacteria hybridizing with both probes appear yellow. Arrows (in $\mathrm{f}$ ) indicate autofluorescence of wood particles. Bars, $50 \mu \mathrm{m}$.
Trichonympha, but from which only two distinct phylotypes of 'Endomicrobia' were recovered, does not necessarily contradict the proposed host specificity. It is possible that the third phylotype of 'Endomicrobia' was missed in this study because it had been under-represented in the sample, or that one of the three phylotypes of Trichonympha in $H$. sjoestedti lacks 'Endomicrobia'. The first explanation is supported by the presence of another 'Endomicrobia' lineage (WG1) recovered from total-gut DNA that clusters with the two other lineages from the Trichonympha suspension (Fig. 2).

All 'Endomicrobia' phylotypes associated with Trichonympha species collectively constitute a monophyletic group that is phylogenetically distinct from the phylotypes recovered from all other flagellates. The evidence that host-specificity is present also at the species level is indicative of co-speciation between the partners (Page \& Charleston, 1998). This would imply that each of the extant Trichonympha flagellates harbours a specific lineage of 'Endomicrobia' inherited by vertical transmission from their common ancestor - an issue that cannot be resolved based on the current dataset. Conversely, it is possible that at one point in time 'Endomicrobia' have been horizontally transferred from one flagellate species to another within the same termite gut. This would explain why oxymonads (Dinenympha, Oxymonas) harbour 'Endomicrobia' that are relatively closely related to the symbionts of parabasalids, i.e. flagellates of a different phylum.

This study corroborates that 'Endomicrobia' form a separate line of descent in the bacterial tree (Stingl et al., 2005). They are part of the TG-1 phylum, which consists of numerous diverse and deep-branching lineages (Herlemann et al., 2007). While 'Endomicrobia' seem to be restricted to termites and wood-feeding cockroaches, other representatives of the TG- 1 phylum occur in a wide range of chemically and geographically distinct habitats, including soils, sediment and intestinal tracts.

Although nothing is known about the metabolic function of 'Endomicrobia', their constant occurrence as intracellular symbionts with a broad host range suggests that their nutritional requirements may be met by substances commonly available in the cytoplasm of gut flagellates. The host flagellates may also benefit from their endosymbionts, e.g. by the provision of nutrients otherwise lacking in the diet of the termites (see also: Stingl et al., 2005). Although certain termite gut flagellates have been shown to ferment cellulose to hydrogen and acetate (Hungate, 1955; Yamin, 1980, 1981; Odelson \& Breznak, 1985), the physiology of most termite gut flagellates is still completely unknown. This makes elucidation of the biology of 'Endomicrobia' and their function in the symbiosis a most intriguing, but very challenging subject. 


\section{ACKNOWLEDGEMENTS}

This work was supported by the Max Planck Society and by a fellowship of the Deutscher Akademischer Austauschdienst (DAAD) to W. I.-O. The authors are grateful to Ai Fujita, Horst Hertel, Judith Korb and Jared R. Leadbetter for providing some of the termites used in this study. We thank Renate Radek for the photomicrograph of Deltotrichonympha operculata and Sibylle Frankenberg for the Oxymonas sp. SSU rRNA gene sequence.

\section{REFERENCES}

Amann, R. I., Krumholz, L. \& Stahl, D. A. (1990). Fluorescentoligonucleotide probing of whole cells for determinative, phylogenetic, and environmental studies in microbiology. J Bacteriol 172, 762-770.

Berchtold, M., Chatzinotas, A., Schönhuber, W., Brune, A., Amann, R., Hahn, D. \& König, H. (1999). Differential enumeration and in situ localization of micro-organisms in the hindgut of the lower termite Mastotermes darwiniensis by hybridization with rRNA-targeted probes. Arch Microbiol 172, 407-416.

Brugerolle, G. \& Bordereau, C. (2004). The flagellates of the termite Hodotermopsis sjoestedti with special reference to Hoplonympha, Holomastigotes and Trichomonoides trypanoides n. comb. Eur J Protistol 40, 163-174.

Brugerolle, G. \& Lee, J. J. (2000). Phylum Parabasalia, In An Illustrated Guide to the Protozoa, 2nd edn, vol. 2, pp. 1196-1250. Edited by J. J. Lee, G. F. Leedale \& P. Bradbury. Lawrence, KS, USA: Society of Protozoologists.

Brune, A. (2006). Symbiotic associations between termites and prokaryotes. In The Prokaryotes, 3rd edn, vol. 1, Symbiotic Associations, Biotechnology, Applied Microbiology, pp. 439-474. Edited by M. Dworkin, S. Falkow, E. Rosenberg, K.-H. Schleifer \& E. Stackebrandt. New York: Springer.

Brune, A. \& Stingl, U. (2005). Prokaryotic symbionts of termite gut flagellates: phylogenetic and metabolic implications of a tripartite symbiosis. In Molecular Basis of Symbiosis, pp. 39-60. Edited by J. Overmann. Berlin: Springer.

Dacks, J. B., Silberman, J. D., Simpson, A. G. B., Moriya, S., Kudo, T., Ohkuma, M. \& Redfield, R. J. (2001). Oxymonads are closely related to the excavate taxon Trimastix. Mol Biol Evol 18, 1034-1044.

Edwards, U., Rogall, T., Blöcker, H., Emde, M. \& Böttger, E. C. (1989). Isolation and direct complete nucleotide determination of entire genes. Characterization of a gene coding for $16 \mathrm{~S}$ ribosomal RNA. Nucleic Acids Res 17, 7843-7853.

Gerbod, D., Edgcomb, V. P., Noël, C., Delgado-Viscogliosi, P. \& Viscogliosi, E. (2000). Phylogenetic position of parabasalid symbionts from the termite Calotermes flavicollis based on small subunit rRNA sequences. Int Microbiol 3, 165-172.

Gerbod, D., Noël, C., Dolan, M. F., Edgcomb, V. P., Kitade, O., Noda, S., Dufernez, F., Ohkuma, M., Kudo, T. \& other authors (2002). Molecular phylogeny of parabasalids inferred from small subunit rRNA sequences, with emphasis on the Devescovinidae and Calonymphidae (Trichomonadea). Mol Phylogenet Evol 25, 545-556.

Henckel, T., Friedrich, M. \& Conrad, R. (1999). Molecular analyses of the methane-oxidizing microbial community in rice field soil by targeting the genes of the $16 \mathrm{~S}$ rRNA, particulate methane monooxygenase, and methanol dehydrogenase. Appl Environ Microbiol 65, 1980-1990.

Herlemann, D. P. R., Geissinger, O. \& Brune, A. (2007). The Termite Group I phylum is highly diverse and widespread in the environment. Appl Environ Microbiol (in press).
Hongoh, Y., Ohkuma, M. \& Kudo, T. (2003). Molecular analysis of bacterial microbiota in the gut of the termite Reticulitermes speratus (Isoptera, Rhinotermitidae). FEMS Microbiol Ecol 44, 231-242.

Hongoh, Y., Deevong, P., Inoue, T., Moriya, S., Trakulnaleamsai, S., Ohkuma, M., Vongkaluang, C., Noparatnaraporn, N. \& Kudo, T. (2005). Intra- and interspecific comparisons of bacterial diversity and community structure support coevolution of gut microbiota and termite host. Appl Environ Microbiol 71, 6590-6599.

Huber, T., Faulkner, G. \& Hugenholtz, P. (2004). Bellerophon: a program to detect chimeric sequences in multiple sequence alignments. Bioinformatics 20, 2317-2319.

Hugenholtz, P., Goebel, B. M. \& Pace, N. R. (1998). Impact of culture-independent studies on the emerging phylogenetic view of bacterial diversity. J Bacteriol 180, 4765-4774.

Hungate, R. E. (1955). Mutualistic intestinal protists. In Biochemistry and Physiology of Protists, vol. 2, pp. 159-199. Edited by S. H. Hutner \& A. Lwoff. New York: Academic Press.

Keeling, P. J., Poulsen, N. \& McFadden, G. I. (1998). Phylogenetic diversity of parabasalian symbionts from termites, including the phylogenetic position of Pseudotrypanosoma and Trichonympha. J Eukaryot Microbiol 45, 643-650.

Kirby, H., Jr (1941). Organisms living on and in protozoa, In Protozoa in Biological Research, pp. 1009-1113. Edited by G. N. Calkins \& F. M. Summers. New York: Columbia University Press.

Loy, A., Horn, M. \& Wagner, M. (2003). probeBase: an online resource for rRNA-targeted oligonucleotide probes. Nucleic Acids Res 31, 514-516.

Ludwig, W., Strunk, O., Westram, R., Richter, L., Meier, H., Yadhukumar, Buchner, A., Lai, T., Steppi, S. \& other authors (2004). ARB: a software environment for sequence data. Nucleic Acids Res 32, 1363-1371.

Moriya, S., Dacks, J. B., Takagi, A., Noda, S., Ohkuma, M., Doolittle, W. F. \& Kudo, T. (2003). Molecular phylogeny of three oxymonad genera: Pyrsonympha, Dinenympha and Oxymonas. J Eukaryot Microbiol 50, 190-197.

Noda, S., lida, T., Kitade, O., Nakajima, H., Kudo, T. \& Ohkuma, M. (2005). Endosymbiotic Bacteroidales bacteria of the flagellated protist Pseudotrichonympha grassii in the gut of the termite Coptotermes formosanus. Appl Environ Microbiol 71, 8811-8817.

Noda, S., Inoue, T., Hongoh, Y., Nalepa, C. A., Vongkaluang, C., Kudo, T. \& Ohkuma, M. (2006). Identification and characterization of ectosymbionts of distinct lineages in Bacteroidales attached to flagellated protists in the gut of termites and a wood-feeding cockroach. Environ Microbiol 8, 11-20.

Odelson, D. A. \& Breznak, J. A. (1985). Nutrition and growth characteristics of Trichomitopsis termopsidis, a cellulolytic protozoan from termites. Appl Environ Microbiol 49, 614-621.

Ohkuma, M. \& Kudo, T. (1996). Phylogenetic diversity of the intestinal bacterial community in the termite Reticulitermes speratus. Appl Environ Microbiol 62, 461-468.

Ohkuma, M., Ohtoko, K., lida, T., Tokura, M., Moriya, S., Usami, R., Horikoshi, K. \& Kudo, T. (2000). Phylogenetic identification of hypermastigotes, Pseudotrichonympha, Spirotrichonympha, Holomastigotoides, and parabasalian symbionts in the hindgut of termites. $J$ Eukaryot Microbiol 47, 249-259.

Ohkuma, M., Noda, N. S., lida, T. \& Kudo, T. (2001). Abstract P.15.006. In 9th International Symposium on Microbial Ecology, Amsterdam, 2001.

Ohkuma, M., lida, T., Ohtoko, K., Yuzawa, H., Noda, S., Viscogliosi, E. \& Kudo, T. (2005). Molecular phylogeny of parabasalids inferred from small subunit rRNA sequences, with emphasis on the Hypermastigea. Mol Phylogenet Evol 35, 646-655. 
Page, R. D. M. \& Charleston, M. (1998). Trees within trees: phylogeny and historical associations. Trends Ecol Evol 13, 356-359.

Radek, R., Hausmann, K. \& Breunig, A. (1992). Ectobiotic and endocytobiotic bacteria associated with the termite flagellate Joenia annectens. Acta Protozool 31, 93-107.

Stingl, U. \& Brune, A. (2003). Phylogenetic diversity and whole-cell hybridization of oxymonad flagellates from the hindgut of the woodfeeding lower termite Reticulitermes flavipes. Protist 154, 147-155.

Stingl, U., Maass, A., Radek, R. \& Brune, A. (2004). Symbionts of the gut flagellate Staurojoenina sp. from Neotermes cubanus represent a novel, termite-associated lineage of Bacteroidales: description of 'Candidatus Vestibaculum illigatum'. Microbiology 150, 2229-2235.

Stingl, U., Radek, R., Yang, H. \& Brune, A. (2005). 'Endomicrobia': cytoplasmic symbionts of termite gut protozoa form a separate phylum of prokaryotes. Appl Environ Microbiol 71, 1473-1479.

Tamm, S. L. (1999). Locomotory waves of Koruga and Deltotrichonympha: flagella wag the cell. Cell Motil Cytoskeleton 43, 145-158.

Trager, W. (1934). The cultivation of a cellulose-digesting flagellate, Trichomonas termopsidis, and of certain other termite protozoa. Biol Bull 66, 182-190.

Wallner, G., Amann, R. \& Beisker, W. (1993). Optimizing fluorescent in situ hybridization with rRNA-targeted oligonucleotide probes for flow cytometric identification of microorganisms. Cytometry 14, 136-143.

Weisburg, W. G., Barns, S. M., Pelletier, D. A. \& Lane, D. J. (1991). 16 S ribosomal DNA amplification for phylogenetic study. J Bacteriol 173, 697-703.

Yamin, M. A. (1979). Flagellates of the orders Trichomonadida Kirby, Oxymonadida Grassé, and Hypermastigida Grassi \& Foà reported from lower termites (Isoptera families Mastotermitidae, Kalotermitidae, Hodotermitidae, Termopsidae, Rhinotermitidae, and Serritermitidae) and from the wood-feeding roach Cryptocercus (Dictyoptera: Cryptocercidae). Sociobiology 4, 3-119.

Yamin, M. A. (1980). Cellulose metabolism by the termite flagellate Trichomitopsis termopsidis. Appl Environ Microbiol 39, 859-863.

Yamin, M. A. (1981). Cellulose metabolism by the flagellate Trichonympha from a termite is independent of endosymbiotic bacteria. Science 211, 58-59.

Yang, H., Schmitt-Wagner, D., Stingl, U. \& Brune, A. (2005). Niche heterogeneity determines bacterial community structure in the termite gut (Reticulitermes santonensis). Environ Microbiol 7, 916-932.

Edited by: H. L. Drake 